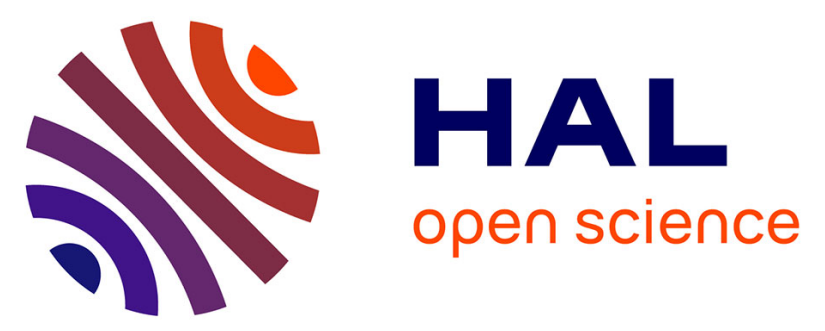

\title{
To return or not to return for STI-HIV tests results: A study among 214 patients screened positive in a free center in Paris offering SMS reminders to reduce failure to return
}

\author{
Camille Rolland, Christophe Segouin, Elise de La Rochebrochard, Marc \\ Shelly, Pénélope Troude
}

\section{To cite this version:}

Camille Rolland, Christophe Segouin, Elise de La Rochebrochard, Marc Shelly, Pénélope Troude. To return or not to return for STI-HIV tests results: A study among 214 patients screened positive in a free center in Paris offering SMS reminders to reduce failure to return. Epidemiology and Public Health = Revue d'Epidémiologie et de Santé Publique, 2018, 66 (Suppl. 5), pp.S405. 10.1016/j.respe.2018.05.459 . hal-02367059

\section{HAL Id: hal-02367059 \\ https://hal.science/hal-02367059}

Submitted on 17 Nov 2019

HAL is a multi-disciplinary open access archive for the deposit and dissemination of scientific research documents, whether they are published or not. The documents may come from teaching and research institutions in France or abroad, or from public or private research centers.
L'archive ouverte pluridisciplinaire HAL, est destinée au dépôt et à la diffusion de documents scientifiques de niveau recherche, publiés ou non, émanant des établissements d'enseignement et de recherche français ou étrangers, des laboratoires publics ou privés. 
Rolland Camille, Segouin Christophe, La Rochebrochard Elise (de), Shelly Marc, Troude Pénélope, 2018, «To return or not to return for STI-HIV tests results: a study among 214 patients screened positive in a free center in Paris offering SMS reminders to reduce failure to return 》, Revue d'Epidémiologie et de Santé Publique, 66, Suppl. 5, p. S405. DOI: 10.1016/j.respe.2018.05.459.

\title{
To return or not to return for STI-HIV tests results: A study among $\mathbf{2 1 4}$ patients screened positive in a free center in Paris offering SMS reminders to reduce failure to return
}

\author{
C. Rolland ${ }^{a, b, *}$, C. Segouin a, ${ }^{a, b}$ E. de La Rochebrochard ${ }^{c, d}$, M. Shelly ${ }^{b}$, P. Troude ${ }^{a, b, c}$ \\ a Public Health Department, University Hospital Center Saint-Louis - Lariboisière - Fernand-Widal, AP- \\ HP, Paris, France \\ ${ }^{\mathrm{b}}$ Free Testing Center for STI, University Hospital Center Saint-Louis - Lariboisière - Fernand-Widal, AP- \\ HP, Paris, France \\ ' Epidemiology Department, Institut National d'Études Démographiques (INED), Paris, France \\ d Epidemiology Department, Paris-Saclay University, Paris-Sud University, UVSQ, CESP, Inserm, Paris, \\ France \\ ${ }^{*}$ Corresponding author. E-mail address: rollandcamille@ymail.com (C. Rolland)
}

INTRODUCTION. Sexually transmitted infections (STI) are a major challenge in public health as nearly one million people become infected every day in the world with chlamydia, gonorrhoea, syphilis or trichomoniasis. Moreover, 2 millions of people become infected every year with HIV in the world. Despite progress in treatment and screening, incidence of STI continues to increase. To decrease the spread of STI, it is needed not only to focus on screening access but also to reduce the high proportion, $15-20 \%$, of patients screened positive for at least one STI and who do not come back for their results generating delay in their medical care and risks of STI transmitting to their partners. In our free testing center for STI in Paris (France), in order to reduce failure to return, patients are offered the possibility of being notified by SMS after testing. If at least one of the STI results is positive, the SMS invites the patient to come back to the center to obtain his/her results. However, even when informed by up to three SMS, a part of patients still fails to return. To target improvement actions, it is needed to define their profile. This study aimed to explore factors associated with failure to return within 30 days after testing (FTR30) among patient screened positive for STI. 
METHODS. Between October 2016 and May 2017, all patients with at least one positive result for STI testing (HIV, HBV, HVC, syphilis, gonorrhea and chlamydia) and who accepted to participate in the study were included $(n=214)$. Data were collected from the consultation database and a selfadministered questionnaire. The FTR30 was measured based on information in the consultation database. This database also includes data on STI tested and results of the screenings performed. The self-questionnaire included sociodemographic factors, sexual behavior and factors related to the center visit. Factors associated with FTR30 were assessed using logistic regression models. The choice of the final multivariate model was based on the result of a backward stepwise selection with a 0.2 significance level for removal from the model.

RESULTS. More than two-thirds of patients were men (72\%), and the median age of patients was 27 years. Most patients were born in metropolitan France $(56 \%)$ or in sub-Saharan Africa $(25 \%)$. Men having sex with men represented $30 \%$ of the study population. The FTR30 rate was $14 \%(95 \% \mathrm{Cl}[10 \%$ $>19 \%]$ ). Even if non-significant, FTR30 tend to be lower among the $72 \%$ of patients who accepted to be notified by SMS than among patients who did not ( $12 \%$ vs. $20 \%$, P 0.10$)$. In multivariate analysis, patients aged 25 or under were more likely to not return than patients older than 25 (aOR: 2.84; 95\% $\mathrm{CI}$ : 1.09-7.41). A lower self-perceived risk of HIV infection was significantly associated with FTR30 (aOR: 3.05; 95\% Cl: 1.17-7.94), as well as not being tested for chlamydia and gonorrhea using self-swabbing (aOR: 5.98; 95\% Cl: 2.03-17.6). Probability of FTR30 was higher for patients coming with someone (aOR: $3.73 ; 95 \% \mathrm{Cl}: 1.41-9.88$ ) compared to patients coming alone.

CONCLUSIONS. The SMS program was well accepted but had a limited impact on FTR30 in our study population. To reduce the risk of failure in delivering STI screening results, systematic phone call after testing might also be proposed to patients. Moreover, no self-swabbing for chlamydia and gonorrhea testing and a lower self-perceived risk of HIV infection were associated with a higher probability of FTR30. Thus, improving STI/HIV knowledge and level of health literacy to empower patients would be an efficient way to decrease failure to return for results.

DISCLOSURE OF INTEREST. The authors declare that they have no competing interest. 